\title{
Fermentative Production of Engineered Cationic Antimicrobial Peptide from Economically Feasible Bacterial Host E. coli GJ1158
}

\author{
J. B. Peravali ${ }^{\# *}$, Seetha Ram Kotra ${ }^{1 \#}$, S. K. Suleyman, T. C. Venkateswarlu ${ }^{2}$, \\ KV Rajesh, K. Sobha ${ }^{3}$ and K. K. Pulicherla ${ }^{4}$ \\ Department of Biotechnology, Bapatla Engineering College, \\ Bapatla - 522101, India \\ ${ }^{1}$ Department of Biotechnology, Acharya Nagarjuna University, \\ Guntur - 522510, India \\ ${ }^{2}$ Department of Biotechnology, Vignan University, \\ Guntur - 522213, India \\ ${ }^{3}$ Department of Biotechnology, RVR\&JC CoE, \\ Guntur - 522019, India \\ ${ }^{4}$ CBST, VIT University, Vellore - 632014, Tamilanadu, India. \\ \# Authors have equal contribution in this work \\ *Corresponding author: jbperavali@gmail.com; +919494152489
}

\begin{abstract}
Production of antimicrobial peptides has gained lot of significance in the present day research. Most of the recombinant proteins are generally produced from IPTG inducible E. coli BL21(DE3). As an alternative, considering the factors like cost and toxic nature of IPTG, salt inducible Escherichia coli GJ1158 was used in the present study for the production of synthetic cationic antimicrobial peptide by fed batch fermentation. This study was conducted to optimize the physico-chemical parameters viz., dissolved oxygen concentration (DOC) and nutritional factors viz., carbon, nitrogen and phosphate sources on bacterial growth and peptide production. Even after increase in DOC more than $30 \%$ in batch culture has no effect on expression, but significant improvement in fed-batch cultivation was observed beyond 30\% DOC. Supplementation of production medium with different pulses of nutrient sources like dextrose mono hydrate, yeast extract and $\mathrm{Na}_{2} \mathrm{HPO}_{4}$ enhanced the expression in fed batch fermentation process even without disturbing the cell growth at $40 \%$ DOC. When growth reached $15 \mathrm{~g} / \mathrm{L}$ of dry cell weight, culture was induced with $150 \mathrm{mM} \mathrm{NaCl}$ and further cultured for next $15 \mathrm{hr}(16.37 \mathrm{~g} / \mathrm{L}$ dry cell weight). Approximately, $258 \mathrm{mg} / \mathrm{L}$ of pure peptide was obtained by using modified GYEON medium. The peptide thus produced is tested for its antimicrobial activity, devoid of hemolytic activity. The fed-batch fermentation which emphasizes, this was the highest reported concentration of recombinant synthetic peptide from salt inducible expression host till to date, which manages to gratify the present day industrial production of the peptides cost-effectively.
\end{abstract}

Keywords: Escherichia coli GJ1158, DOC, batch culture, fed batch fermentation, synthetic cationic antimicrobial peptide

\section{Introduction}

Numerous diseases are increasingly difficult to treat with currently available antibiotics is a major concern worldwide because of the emergence of drug resistant organisms including bacteria, fungi and viruses. Antimicrobial peptides are the upcoming therapeutic molecules as alternative drugs to the antibiotics. These peptides have a good scope in current antibiotic research [1]. Antimicrobial peptides work against a wide range of 
pathogenic organisms in different ways of mechanisms where there will be almost negligible chance of getting resistance by the organism against these peptides. Usually these antimicrobial peptides have 10-50 amino acids in size and show its antimicrobial activity by interacting, disturbing their cell wall, cell membrane and at various intracellular targets [2]. These AMPs are identified in various prokaryotic and eukaryotic sources, but all these molecules are facing the problems viz., fast proteolysis, a poor absorption due to their hydrophilicity, and high cost of development, systemic and local toxicity [3]. For this reasons r-DNA technology was explored to produce the protein in large quantity with the use of cost effective media. E. coli is one of the most extensively used and accepted host for recombinant protein production [4-10]. E. coli BL21(DE3) is most commonly used host for production, but some struggles associated with BL21 were cost of IPTG and toxicity. To overcome many of such hindrances experiments with salt inducible expression host like E. coli GJ1158 was used for the heterologous protein expression where the protein yield was slightly reduced, but activity of the recombinant protein was not compromised [11]. The recombinant protein expression was slightly enhanced even if the cultivation was switched from shake flask to reactor level. Therefore some influential parameters need to be optimized for cell proliferation and protein expression that includes in particular nutritional factors like carbon, nitrogen and phosphate sources to the host cells. The effect of oxygen transfer rate and dissolved oxygen are the two aspects for the cultivation process [12]. The dissolved oxygen in the range of $30-50 \%$ yields the optimal expression level of different recombinant proteins during fed-batch cultivation [13-15]. But in many E. coli fermentation studies the expression levels was elevated with the addition of different nutritional factors.

In this study, we used recombinant strain E. coli GJ1158 pRSET-A synthetic cationic antimicrobial peptide was constructed in our lab (data not shown here). The study was designed to check the influence of dissolved oxygen, nutritional factors like glucose, yeast extract and $\mathrm{Na}_{2} \mathrm{HPO}_{4}$ on over production of synthetic cationic antimicrobial peptide from the above construct of salt inducible expression host E. coli GJ1158

\section{Materials and Methods}

\subsection{Strains and Plasmid}

Expression host E. coli GJ1158 was procured from Genei, Bangalore. The gene was cloned under the control of strong T7 promoter and lac operator in pRSET-A vector, which contains antibiotic resistance gene as selectable marker. The r-DNA was maintained in the host E. coli DH5 $\alpha$. The recombinant plasmid was isolated and transformed into GJ1158 for fermentation studies. Recombinant plasmid contained the ampicillin resistance gene for selection of plasmid containing bacterial clones was maintained in $40 \%$ sterile glycerol at $-80{ }^{\circ} \mathrm{C}$.

\subsection{Media Preparation}

LBON broth (1 \% tryptone and $0.5 \%$ yeast extract, $\mathrm{pH} 6.8 \pm 0.2)$ was used for the propagation of bacterial culture. Fermentation was carried on modified GYE media (MGYEON) (a) $\mathrm{Na}_{2} \mathrm{HPO}_{4}-6 \mathrm{~g} / \mathrm{L}$, (b) $\mathrm{KH}_{2} \mathrm{PO}_{4}-3 \mathrm{~g} / \mathrm{L}$, (c) $\mathrm{NH}_{4} \mathrm{Cl}-1 \mathrm{~g} / \mathrm{L}$, (d) $\left(\mathrm{NH}_{4}\right)_{2} \mathrm{SO}_{4}$ - $3.6 \mathrm{~g} / \mathrm{L}$, (e) Yeast extract $-5 \mathrm{~g} / \mathrm{L}$, (f) Glucose $-11 \mathrm{~g} / \mathrm{L}$, (g) $1 \mathrm{M} \mathrm{MgSO}_{4}-2 \mathrm{~mL}$, (h) TMM - $1 \mathrm{~mL}\left(\mathrm{Al}_{2}\left(\mathrm{SO}_{4}\right)_{3} .7 \mathrm{H}_{2} \mathrm{O}-10 \mathrm{mg} / \mathrm{L}, \mathrm{CuSO}_{4} . \mathrm{H}_{2} \mathrm{O}-2 \mathrm{mg} / \mathrm{L}, \mathrm{H}_{3} \mathrm{BO}_{4}-1 \mathrm{mg} / \mathrm{L}\right.$, $\mathrm{MnCl}_{3} .4 \mathrm{H}_{2} \mathrm{O}-20 \mathrm{mg} / \mathrm{L}, \mathrm{NiCl}_{2} .6 \mathrm{H}_{2} \mathrm{O}-1 \mathrm{mg} / \mathrm{L}, \mathrm{Na}_{2} \mathrm{MoO}_{4} .2 \mathrm{H}_{2} \mathrm{O}-50 \mathrm{mg} / \mathrm{L}, \mathrm{ZnSO}$. $7 \mathrm{H}_{2} \mathrm{O}-50 \mathrm{mg} / \mathrm{L}, \mathrm{FeSO}_{4}-50 \mathrm{mg} / \mathrm{L}$ ). Each and every component of the medium was autoclaved separately for $15-20 \mathrm{~min}$ at $121{ }^{\circ} \mathrm{C}$. The production medium was constituted by mixing the above ingredients aseptically. $\mathrm{NaCl}$ was excluded while working with GJ1158. 


\subsection{Inoculum Preparation}

A loopful of inoculum from $40 \%$ glycerol stock was streaked on LBON agar plate (ampicillin concentration $100 \mathrm{\mu gml}^{-1}$ ) and incubated at $37{ }^{\circ} \mathrm{C}$ for overnight. A loopful of single colony was transferred to LBON broth and incubated on a rotary shaker at $37^{\circ} \mathrm{C}$ for $6-8$ hrs at $150 \mathrm{rpm}$. After the incubation time, $6 \%$ of the pre-inoculum was transferred to MGYEON medium and incubated at $37{ }^{\circ} \mathrm{C}$ for 4-6 hrs.

\subsection{Shake Flask Cultivation}

$5 \%$ inoculum was transferred to the $100 \mathrm{ml}$ working volume of LBON and MGYEON broth and incubated on a rotary shaker at $37{ }^{\circ} \mathrm{C}$ and $150 \mathrm{rpm}$. When the cell density $\left(\mathrm{OD}_{600}\right)$ reached to 2.6 in LBON broth and 2.4 in MGYEON medium, $150 \mathrm{mM}$ sterile $\mathrm{NaCl}$ was added aseptically and allowed for incubation on a rotary shaker at $37{ }^{\circ} \mathrm{C}$ and 150 rpm for 4 hrs.

\subsection{Fermentation}

Fermentation trials were conducted using 5 ltr bioreactor (Spectrochem Instrument Pvt. Ltd, Hyd) with a working volume of 3.0 ltrs. Sterile $5 \mathrm{~N} \mathrm{NaOH}$ (Sodium hydroxide) and $3 \mathrm{~N} \mathrm{HCl}$ (Hydrochloric acid) were used as $\mathrm{pH}$ controlling agents. For batch and fed batch cultivations, different stocks of $\mathrm{DMH}, \mathrm{Na}_{2} \mathrm{HPO}_{4}$ and trace metal mix were prepared and autoclaved separately. After autoclaving of remaining components or before addition of inoculum to the fermentor vessel, stocks were be added in appropriate amounts. Later, three feed bottles containing dextrose mono hydrate, yeast extract and $\mathrm{Na}_{2} \mathrm{HPO}_{4}$ were attached to fermentor vessel under aseptic conditions. Sterile polypropylene glycol was used as an antifoaming agent.

2.5.1. Batch Fermentation: Induction was carried out when the cell density $\left(\mathrm{OD}_{600}\right)$ of the batch culture reached 12 from LBON medium and 9.0 from MGYEON medium (at 7$8 \mathrm{hrs}$ ). After induction, the culture was harvested for 4-5 hrs. The dissolved oxygen percentage was maintained at 30 (before and after induction) by cascading agitation rate (500-750 rpm). The constant aeration rate was maintained at $1.25 \pm 0.25 \mathrm{vvm}$.

2.5.2. Fed Batch Fermentation: After complete consumption of nutritional factors the batch cultivations were switched towards fed batch cultures. 4-6 hrs of post induction was carried after inducing with $150 \mathrm{mM} \mathrm{NaCl}$ when the $\mathrm{OD}_{600}$ reached around 30 ( $17-18$ hours). $30 \%$ DO was maintained as the set point by cascading impeller speed. Oxygen enrichment was recorded as percentage of pure oxygen added to the total air/gas (taken as $100 \%$ ) supplied for aeration [16]. After three hours of inoculation, a pulse of dextrose monohydrate was given at the rate of $2 \mathrm{gm} / \mathrm{lit} / \mathrm{hr}$ for first three hours. This was enhanced to $4 \mathrm{gm} / \mathrm{lit} / \mathrm{hr}$ for the next six hours. Likewise, a pulse of yeast extract is given at the rate of $4 \mathrm{gm} / \mathrm{lit} / \mathrm{hr}$ for first three hours and $8 \mathrm{gm} / \mathrm{lit} / \mathrm{hr}$ for next six hours and also a pulse of $\mathrm{Na}_{2} \mathrm{HPO}_{4}$ is given at the rate of $1 \mathrm{gm} / \mathrm{lit} / \mathrm{hr}$ for first three hours and $2 \mathrm{gm} / \mathrm{lit} / \mathrm{hr}$ for next six hours. While giving the pulse the wet weight of the biomass was determined at the regular intervals of time and when the cell density reached to $30(\sim 15 \mathrm{~g} / \mathrm{L})$, appropriate concentration of sterile inducer was added $(150 \mathrm{mM} \mathrm{NaCl})$ and rate of pulse of three components gradually reduced to $80 \%$ for first three hours, $60 \%$ for the next three hours, $40 \%$ for the next three hours, $20 \%$ for the next three hours and at the 0 feed rate at the last three hours of post induction.

\subsection{Analytical Methods}

Glucose levels in the medium was determined by 3,5-dinitrosalicylic acid (DNS) method [17]. One optical density $\left(\mathrm{OD}_{600}\right)$ unit was found to be equivalent to $0.5 \mathrm{~g}$ DCW. 
After induction, cell pellets were dissolved in phosphate buffered saline (PBS) and sample solubilizing buffer (0.0625 M Tris - $\mathrm{HCl}(\mathrm{pH}$ 6.8), $5 \%$ $\% \mathrm{ME}, 2 \% \mathrm{SDS}, 10 \%$ glycerol, $0.01 \%$ bromophenol blue) and boiled at $100{ }^{\circ} \mathrm{C}$ for $10 \mathrm{~min}$. Samples were run on $18 \%$ tricine-SDS-PAGE with reference to the low range protein marker. To investigate both the soluble and insoluble fractions, cells were lysed by sonication [18]. After sonication, the samples were loaded on $18 \%$ tricine-SDS-PAGE [19].

\subsection{Purification of Recombinant Camp}

The recombinant peptide carrying an N-terminal 6X His tag was expressed in E. coli GJ1158 and purified using affinity chromatography with $\mathrm{Ni}^{2+}$ - resin under hybrid conditions. In order to purify recombinant peptide, $400 \mathrm{mg}$ wet cells were obtained from a freshly grown $50 \mathrm{ml}$ culture in LBON and MGYEON, containing the appropriate antibiotic. The cells were harvested and centrifuged at 13,800 rpm for $20 \mathrm{~min}$ at $4{ }^{\circ} \mathrm{C}$ and the pellet attained was suspended in $6 \mathrm{ml}$ of guanidinium lysis buffer containing $7 \mathrm{M}$ guanidine $\mathrm{HCl}, 22 \mathrm{mM}$ sodium phosphate, $510 \mathrm{mM} \mathrm{NaCl}$ with $\mathrm{pH} 7.8$ at $4{ }^{\circ} \mathrm{C}$ for $1 \mathrm{hr}$. The cell lysate was again centrifuged at $13,800 \mathrm{rpm}$ for 20 to $15 \mathrm{~min}$ at $4{ }^{\circ} \mathrm{C}$. A volume of $5 \mathrm{ml}$ cell lysate was purified on a column containing $2 \mathrm{ml}$ resin equilibrated with denaturing binding buffer, incubated for $45 \mathrm{~min}$ at room temperature with gentle hand shaking for several times. The column was washed with $2 \mathrm{ml}$ of denaturing wash buffer and twice with $2 \mathrm{ml}$ of native wash buffer. The bounded protein was eluted with $2 \mathrm{ml}$ of native elution buffer and analyzed on $18 \%$ separating gel against to protein marker.

\subsection{Antimicrobial activity}

Antimicrobial activity was tested by top agar assay and also by the radial diffusion method on both Gram positive (Staphylococcus aureus) and Gram negative bacteria (Pseudomonas putida) [20]. Bacteria were first grown in LB broth to an $\mathrm{OD}_{600}$ of 0.8 . A $10 \mu \mathrm{L}$ of the bacterial culture was added to $8 \mathrm{~mL}$ of LB broth with $0.7 \%$ agar and poured in petridish containing $25 \mathrm{~mL}$ of $1.5 \% \mathrm{LB}$ agar. After the top agar harden, a $10 \mu \mathrm{L}$ of the test sample was added on the surface of the top agar and completely dried before incubating overnight at $37{ }^{\circ} \mathrm{C}$. If sample containing antimicrobial activity, a zone of clearance was formed on the surface of the top agar representing the inhibition of bacterial growth and ampicillin was used as positive control.

The peptide was further tested for its minimal inhibitory concentration on various bacterial strains [21]. Various concentrations ranging from 5 to $25 \mu \mathrm{g} / \mathrm{ml}$ of peptide (5 $\mu \mathrm{g}$, $10 \mu \mathrm{g}, 15 \mu \mathrm{g}, 20 \mu \mathrm{g}$ and $25 \mu \mathrm{g} / \mathrm{ml}$ ) was added to the optimal diluted bacterial cultures of both Gram positive and Gram negative were incubated at $37{ }^{\circ} \mathrm{C}$ for $3 \mathrm{hrs}$. Further, the three bacterial cultures of above mentioned concentrations were transferred and spread on agar plates and incubated at $37{ }^{\circ} \mathrm{C}$ for overnight. The MIC of peptide concentration was recorded.

\section{Results \& Discussion}

\subsection{Shake flask cultivation}

Recombinant salt inducible E. coli GJ1158 strain was evaluated in shake flasks and synthetic cationic antimicrobial expression levels in LBON and modified GYEON medium (later used for batch and fed batch cultivations) were compared. The protein expression was observed by running $18 \%$ tricine-SDS-PAGE of the samples from LBON and modified GYEON medium were showed in the following Figure 1. 


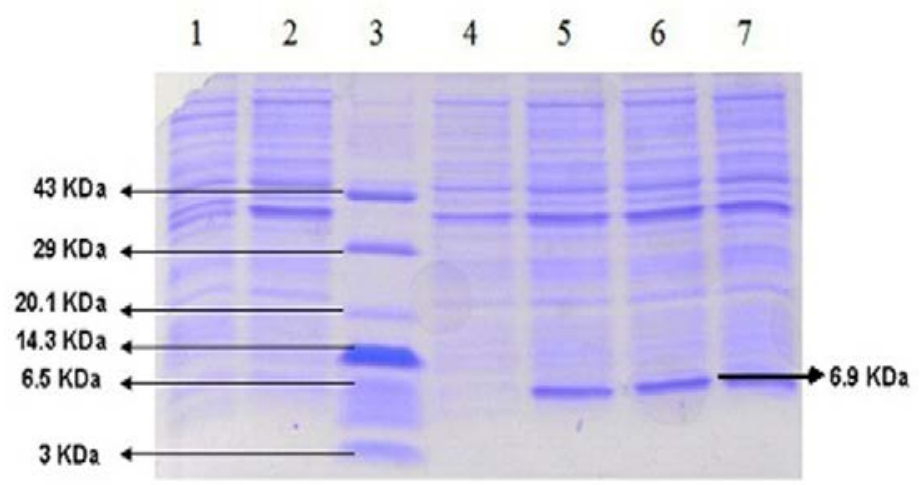

Figure 1. SDS-PAGE of Synthetic Cationic Antimicrobial Peptide

Lane 1: Uninduced pRSET-A E. coli GJ1158; Lane 2: Induced pRSET-A E. coli GJ1158; Lane 3: Low molecular weight protein marker;

Lane 4: Uninduced synthetic cationic antimicrobial peptide pRSET-A E. coli GJ1158; Lane 5: Induced synthetic cationic antimicrobial peptide pRSET-A E. coli GJ1158 (at 30 $\%$ DOC from batch cultivation);

Lane 6 \& 7: Induced synthetic cationic antimicrobial peptide pRSET-A E. coli GJ1158 (at $40 \%$ DOC from fed batch cultivation) with glucose, yeast extract and $\mathrm{Na}_{2} \mathrm{HPO}_{4}$ as pulse.

In LBON broth, the recombinant protein specific yield was $1.5 \mathrm{mg} / \mathrm{L}$. Likewise, in modified GYEON media, the specific yield was $1.2 \mathrm{mg} / \mathrm{l}$. The recombinant protein was expressed in soluble fractions. In this study, the recombinant synthetic cationic AMP production in bacterial expression systems was slightly reduced compared to other $E$. coli strains [38, 40, 41].

\subsection{Batch Cultivation}

Based on the results of shake flask studies, recombinant protein expression was slightly higher in LB broth when compared to modified GYEON medium. Batch cultivation was performed by using modified GYEON medium was carried out in 5 ltr bioreactor with a working volume of 3 ltrs at $30 \%$ dissolved oxygen throughout the experiment. Approximately, similar yield was obtained in modified GYEON media; it is preferred to be run in bioreactor because of its low cost and good specific yield. At final $\mathrm{OD}_{600} \sim 9$ (Figure - 2) in modified GYEON medium and 12 in LBON medium, induced with 150 $\mathrm{mM} \mathrm{NaCl}$ and after 3-4 hrs of post induction process the recombinant specific yield was $79.5 \mathrm{mg} / \mathrm{L}$. It is comparatively low when compared the production from LBON media (84.2 mg/L). Even enhanced DOC beyond 30 \% didn’t influence the enhanced production of recombinant protein.

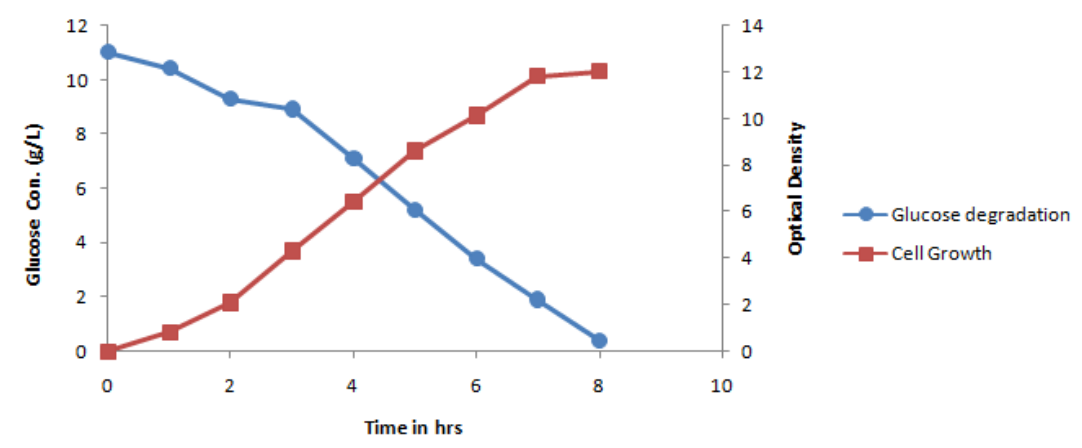

Figure 2. Batch fermentation of synthetic cationic antimicrobial peptide Figure Shows Cell Growth (घ), Glucose Utilization (•) 


\subsection{Fed Batch Cultivation}

Fed batch cultivations were involved by the consequent addition of nutrients like glucose, $\mathrm{Na}_{2} \mathrm{HPO}_{4}$ and yeast extract to build up high density of E. coli cells. Different dissolved oxygen ranges like 20,30, 40 and $50 \%$ were studied. This fed-batch cultivation was run by using $40 \%$ dissolved oxygen as set point under nutrients supply before and after induction process gave maximum yield. An induced fed-batch experiment with $\mathrm{Na}_{2} \mathrm{HPO}_{4}$ for $1 \mathrm{gm} / \mathrm{lt} / \mathrm{hr}$ for first three hours then $2 \mathrm{gm} / \mathrm{lt} / \mathrm{hr}$ for next six hours, yeast extract feeding rate was $4 \mathrm{gm} / \mathrm{lt} / \mathrm{hr}$ for first three hours then $8 \mathrm{gm} / \mathrm{lt} / \mathrm{hr}$ for next six hours and glucose feeding rate was $2 \mathrm{gm} / \mathrm{lt} / \mathrm{hr}$ for first three hours and $4 \mathrm{gm} / \mathrm{lt} / \mathrm{hr}$ for next six hours resulted in a maximum cell density $\left(\mathrm{OD}_{600}\right)$ of 30 within 12 hrs (Figure 3 ).

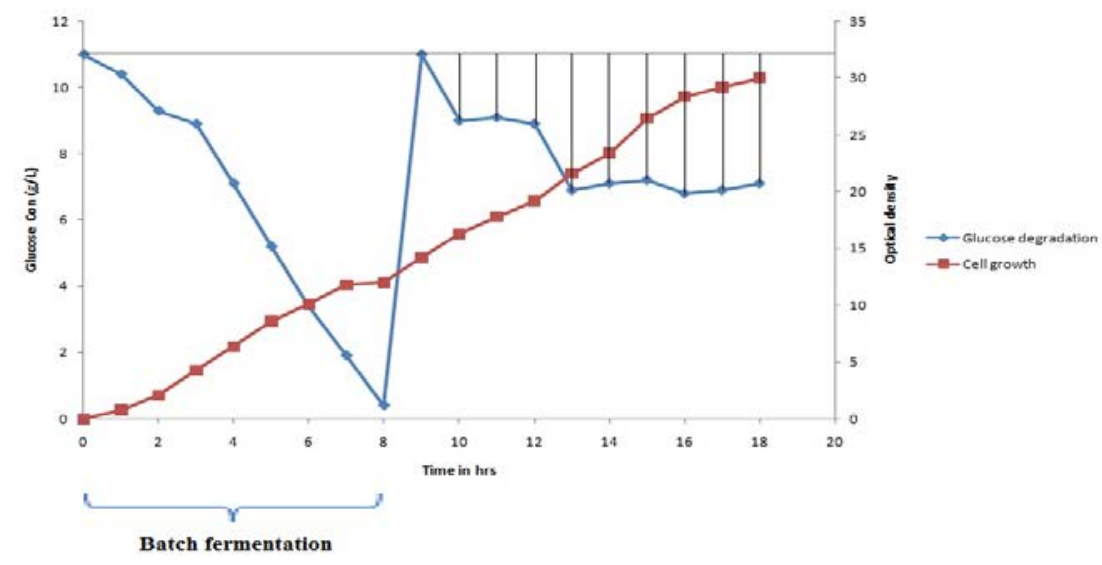

Figure 3. Fed Batch Fermentation Supplied with Dextrose Monohydrate at $40 \%$ DOC. Glucose Utilization ( $\diamond)$ and Optical density at $O D_{600} \mathrm{~nm}(\square)$. Vertical Lines Indicating the Addition of Glucose at each and Every Hour Interval and Finally Maintained $11 \mathrm{~g} / \mathrm{L}$ Throughout the Experiment for Getting Maximum OD upto before Induction Process

The culture was induced with $150 \mathrm{mM} \mathrm{NaCl}$ at $\mathrm{OD}_{600} 30$ (after $12 \mathrm{hrs}$ ), cell density of $32(\sim 16.37 \mathrm{~g} / \mathrm{L})$ was obtained after feeding time of 15 hrs. After specific yield quantification, induction at $\mathrm{OD}_{600} 30$ was noticed as best $\mathrm{OD}$ for induction. The produced recombinant peptide is also having good antimicrobial activity against to different Gram positive and Gram negative micro organisms. At 30\% dissolved oxygen $193 \mathrm{mg} / \mathrm{L}$ protein was achieved. It was 2.42 folds increase in the production when compared to the batch cultivation of synthetic cationic antimicrobial peptide.

\subsection{Effect of Glucose}

In order to improve the cell density to get maximum yield of recombinant protein, concentration of glucose in medium after inoculation was maintained $11 \mathrm{gm} / \mathrm{L}$ throughout the experiment before induction process by providing the pulse $2 \mathrm{gm} / \mathrm{lt} / \mathrm{hr}$ for first 3 hours to $4 \mathrm{gm} / \mathrm{lt} / \mathrm{hr}$ for next 6 hours. Each and every time while giving glucose as pulse, OD was recorded. There is no significant difference between the OD at $12^{\text {th }}$ and $13^{\text {th }}$ hour. At $40 \%$ dissolved oxygen, glucose alone as pulse $224 \mathrm{mg} / \mathrm{L}$ protein was achieved is 1.16 folds greater than the protein achieved at $30 \%$ DO in fed batch.

\subsection{Effect of Dissolved Oxygen}

Different levels of dissolved oxygen were studied. $30 \%$ DOC in batch cultivation was resulted good expression level. Whereas, in fed batch fermentation the dissolved oxygen was found to be in the range upto $40 \%$. The value of DOC remained at $30 \%$ in batch 
cultivation, while in fed-batch it was found to be the highest DOC value $40 \%$. $20 \%$ dissolved oxygen cioncentration is enough to produce the recombinant proteins in fed batch cultivation [22]. The threshold level in order to maintain DOC, the next fed-batch cultivation was carried out at $40 \%$ DOC and although the cell growth was slightly increased compared to $30 \%$ DOC and residual glucose profiles were reduced similar to $30 \%$ DOC fed batch fermentation. The number of cells during post-induction phase was not increased. The final enhancement in cell proliferation was observed while giving the pulse to be in direct agreement with increase in the DOC and hence, concentration of recombinant protein, which was estimated to be $258 \mathrm{mg} / \mathrm{L}$, where the combination of glucose, yeast extract and $\mathrm{Na}_{2} \mathrm{HPO}_{4}$ as pulse. So, $40 \%$ of DOC is always effective in fed batch cultivation and increase of DOC to $60 \%$ did not influence the improvement in expression in other experiment trails (data not shown here). In some studies $10 \%$ DOC is enough to produce the protein [23]. But, we achieved highest quantity of protein at $40 \%$ DOC in fed batch. The low and high levels of DOC were not unusual and supposed to happen due to changes in growth kinetics [24, 25], aeration or agitation rates and increase in viscosity [26]. Based on the results, the decrease in level of DO in cultivation medium after induction, below a threshold levels, can affect the cell proliferation and expression of recombinant protein.

Very inconsiderable cell proliferation was observed during the initial 4-5 hrs of post induction time by raising the DOC upto $50 \%$ and the protein expression levels were not enhanced. During the bioreactor cultivations of recombinant E. coli, the maintenance of DOC above a certain threshold level and oscillations in DOC should also be taken in consideration. For this reason the DOC is critical for both growth and it provides the energy for the proliferation of bacteria and expression of the recombinant protein [27]. The initial post-induction time was crucial for the expression of recombinant protein under the strong promoter T7 as product formation was ceased after the $4-5$ hours of induction period $[16,28]$.

\subsection{Effect of Yeast Extract}

To increase the expression of synthetic cationic antimicrobial peptide in fed-batch cultivation, the effect of different nitrogen sources were investigated and yeast extract was identified as the optimial nitrogen source for bacterial growth. This was identified in increased recombinant protein expression [29, 30] and cell mass [31]. The final cell density $\left(\mathrm{OD}_{600}\right)$ in fed batch cultivation was 30 and resulted the highest expression from recombinant E.coli by providing the $4 \mathrm{gm} / \mathrm{l} / \mathrm{hr}$ for first three hours and $8 \mathrm{gm} / \mathrm{l} / \mathrm{hr}$ for next 6 hours to achieve the maximum cell density. The continuous medium supplementation [3234] was resulted the highest specific protein concentration of $258 \mathrm{mg} / \mathrm{L}$ when compared to batch fermentation (84.2 mg/L from LBON broth, $79.5 \mathrm{mg} / \mathrm{L}$ from MGYEON). But on combination with glucose the production yield was $249 \mathrm{mg} / \mathrm{L}$, where the maximum yield was achieved compared to the glucose alone as pulse at $40 \%$ fed batch fermentation (224 $\mathrm{mg} / \mathrm{L})$.

\subsection{Effect of $\mathrm{Na}_{2} \mathrm{HPO}_{4}$}

The phosphorus compounds serve as major nutrients in cell growth and protein expression. A pulse of $\mathrm{Na}_{2} \mathrm{HPO}_{4}$ is given in the rate of $1 \mathrm{gm} / \mathrm{lit} / \mathrm{hr}$ for first three hours. Then pulse has been enhanced to $2 \mathrm{gm} / \mathrm{lit} / \mathrm{hr}$ for next six hours. While giving the pulse the dry weight of the biomass was determined at the regular intervals of time and when the cell density reached to maximum biomass, appropriate concentration of inducer is added $(150 \mathrm{mM} \mathrm{NaCl})$ and after induction, the rate of pulse will gradually reduced to $80 \%$ for first three hours, $60 \%$ for first three hours, $40 \%$ for the next three hours, $20 \%$ for the next three hours and at the 0 feed rate at the last three hours of the induction. The protein 
production was slightly increased (258 $\mathrm{mg} / \mathrm{L})$ along with addition of other nutrients like glucose and yeast extract at $40 \%$ DO in fed batch fermentation [Table-1].

Table 1. Recombinant Synthetic Cationic Antimicrobial Peptide at Different Stages of Production

\begin{tabular}{|c|c|c|c|c|}
\hline Fermentation type & Media used & OD $_{\mathbf{6 0 0}} \mathbf{1}$ & $\begin{array}{c}\text { Dry cell } \\
\text { weight } \\
\text { (g/L) }\end{array}$ & $\begin{array}{c}\text { Specific } \\
\text { peptide } \\
\text { (mg/L) }\end{array}$ \\
\hline Shake flask & LBON & 2.6 & 1.3 & 1.5 \\
\hline Shake flask & MGYEON & 2.4 & 1.1 & 1.2 \\
\hline Batch ferementor & LBON & 12.6 & 5.1 & 84.2 \\
\hline Batch ferementor & MGYEON & 10.4 & 4.5 & 79.5 \\
\hline Fed batch (30 \% DO) & MGYEON & 30 & 15.1 & 193 \\
\hline Fed batch (40 \% DO) & $\begin{array}{c}\text { MGYEON + Glucose as } \\
\text { pulse }\end{array}$ & 30.5 & 15.34 & 224 \\
\hline Fed batch (40 \% DO) & $\begin{array}{c}\text { MGYEON + Glucose + } \\
\text { Yeast extract as pulse }\end{array}$ & 31.3 & 16.19 & 249 \\
\hline Fed batch (40 \% DO) & $\begin{array}{c}\text { MGYEON + Glucose + } \\
\text { YE + Na }{ }_{2} \text { HPO } 4 \text { as pulse }\end{array}$ & 32 & 16.37 & 258 \\
\hline
\end{tabular}

${ }^{1}$ values are \pm means of two experimental trails

The feeding rate of $\mathrm{Na}_{2} \mathrm{HPO}_{4}$ improves the cell biomass and the protein production. Even after increasing the feeding rate more than $6 \mathrm{gm} / \mathrm{lit} / \mathrm{hr}$ after $9^{\text {th }}$ hour does not show any influence on cell proliferation and protein production indicates that maximum feeding rate is $1 \mathrm{gm} / \mathrm{lt} / \mathrm{hr}$ for first three hours and $2 \mathrm{gm} / \mathrm{lt} / \mathrm{hr}$ for next six hours. The essentially unaffected protein yield of antimicrobial peptides with scale up from flask level to fed batch reactor is having practical importance in large scale protein production.

\subsection{Antimicrobial and Hemolytic Activity}

The antimicrobial activity assay was performed to determine the activity of the purified recombinant synthetic cationic AMP. Figure 4 shows that zone of clearance around the well containing recombinant AMP, where control well shows no zone of inhibition.

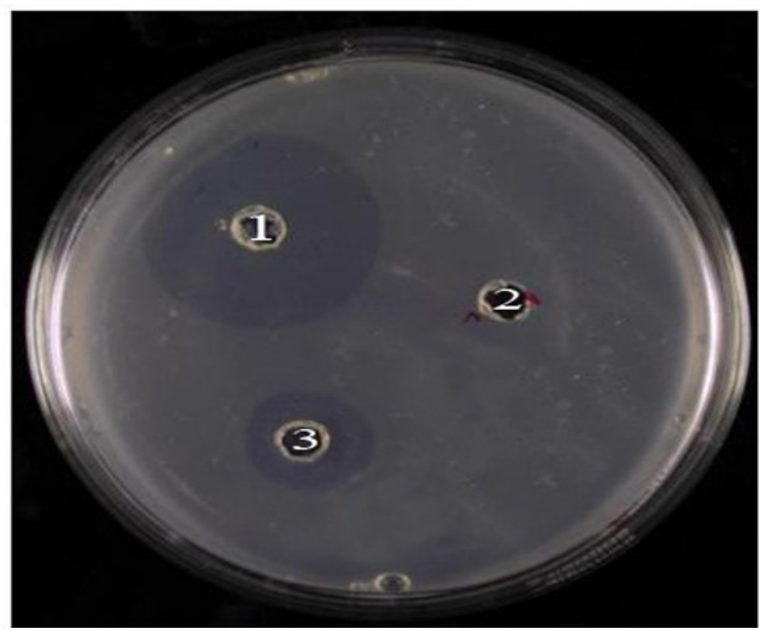

Figure 4. Inhibitory Zone Evaluation of Recombinant Synthetic Cationic AMP on Growth of Staphylococcus Aureus

1: Ampicillin (10 $\mu \mathrm{g} / \mathrm{ml}) ; 2: 1 \mathrm{mM}$ PPB (pH 7.2) as Negative Control; 3: Recombinant Synthetic Peptide $(10 \mu \mathrm{g} / \mathrm{ml})$ 
The MICs of the purified recombinant AMP against Gram-positive and Gram-negative bacteria are in the range of $15-25 \mu \mathrm{g} / \mathrm{ml}$. The antimicrobial effect of different concentration of cAMP on E. coli K12 growth was illustrated in Figure 5.

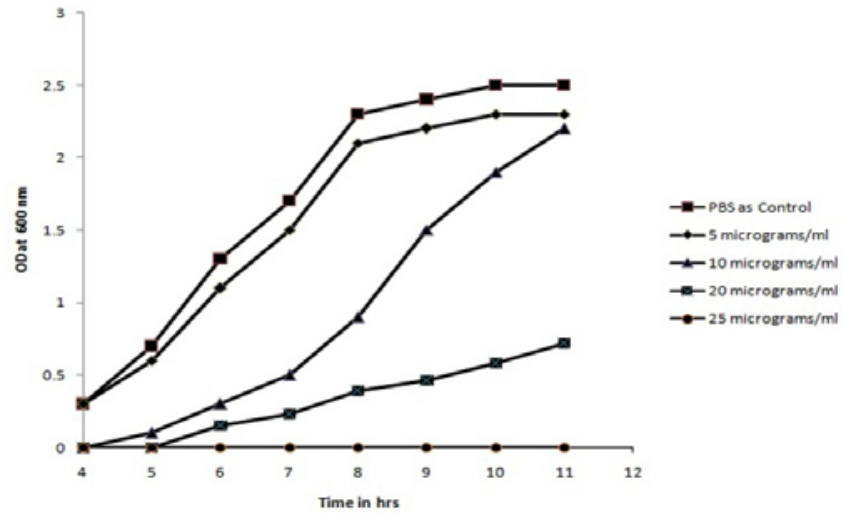

Note: Experiments were performed in duplicates

Figure 5. The Effect of cAMP on the Growth of E. coli K12 Monitored by Measuring the $O D_{600} \mathrm{~nm}$

Some antimicrobial peptides exhibit hemolytic activities but no hemolytic activity was observed after overnight incubation using the concentration of $5-50 \mu \mathrm{g} / \mathrm{ml}$, indicating that cAMP was not toxic to red blood cells.

\section{Conclusion}

The synthetic cationic antimicrobial peptides will have high demand in future because of its maximum potency towards different Gram positive and Gram negative micro organisms. The optimization of cultivation parameters leads to the enhanced production of synthetic cationic antimicrobial peptide is the best of our knowledge from salt inducible system till to date. At flask and batch cultivation level the highest quantity of protein was yielded from LBON medium, very similar results were observed using modified GYEON medium. The amount of recombinant synthetic cationic antimicrobial peptide produced in this study using salt induction system was relatively high when compared with $140 \mathrm{mg} / \mathrm{L}$ Mouse Beta Defensin-1 Mature Peptide [35], $60 \mathrm{mg} / \mathrm{L}$ cationic antimicrobial peptide lactoferricin [36], $1.4 \mathrm{mg} / \mathrm{L}$ of active recombinant CM4 [37], $92 \mathrm{mg} / \mathrm{L}$ of plectasin [38], $13.2 \mathrm{mg} / \mathrm{L}$ of cationic recombinant thanatin analog [39], $1.9 \mathrm{mg} / \mathrm{l}$ recombinant PR-39 [40], $1.1 \mathrm{mg} / \mathrm{l} \mathrm{PG-1} \mathrm{[40]} \mathrm{and} \mathrm{slightly} \mathrm{lower} \mathrm{when} \mathrm{compared} \mathrm{to} 689 \mathrm{mg} / \mathrm{L}$ of mature hBD4 [41], $1.49 \mathrm{~g} / \mathrm{L}$ of fusion protein HBD5, $1.57 \mathrm{~g} / \mathrm{L}$ of fusion protein HBD6 [42]. This study mainly concentrated on influence of dissolved oxygen and other nutritional parameters on growth and recombinant peptide production. Dissolved oxygen (40\%) is the influencing parameter for the production of recombinant peptide on the combination of different nutritional factors. Finally 3.24 folds increase of recombinant synthetic cationic antimicrobial peptide production was observed over the batch fermentor using modified GYEON medium and 1.33 folds of increase was observed when compared with fed batch run, using the same medium with $30 \%$ dissolved oxygen. It helps to know the better conditions for enhanced production of synthetic cationic antimicrobial peptides in large scale bioreactors.

\section{Acknowledgements}

The authors are thankful to Prof. J. Srinivasa Rao, Prof \& Head, Department of Biotechnology, Bapatla Engineering College, Bapatla, Guntur, Andhra Pradesh, India for providing the infrastructure facilities to carry out the work. 


\section{References}

[1] D. Raventos, O. Taboureau, P. H. Mygind, J. D. Nielsen, C. P. Sonksen and H. H. Kristensen, "Improving on nature's defenses: Optimization \& high through put screening of antimicrobial peptides", Comb. Chem High Throughput Screening, vol. 8, (2005), pp. 219-233.

[2] R. M. Epand and H. J. Vogel, "Diversity of antimicrobial peptides and their mechanisms of action", Biochim. Biophys. Acta., vol. 462, (1999), pp. 11-28.

[3] D. Andersons, A. Engstrom, S. Josephson, L. Hansson and H. Steiner, "Biologically active and amidated cecropin produced in a baculovirus expression system from a fusion construct containing the antibodybinding part of protein A”, Bio chem, vol. 280, (1991), pp. 219-224.

[4] I. Cipakova, E. Hostinova, J. Gasperik and V. Velebny, "High level expression and purification of a recombinant hBD-1 fused to LMM protein in Escherichia coli”, Protein Expr. Purif., vol. 37, (2004), pp. 207-212.

[5] S. W. Hwang, J. H. Lee, H. B. Park, S. H. Pyo, J. E. So, H. S. Lee, S. S. Hong and J. H. Kim, “A simple method for the purification of an antimicrobial peptide in recombinant Escherichia coli", Mol. Biotechnol, vol. 18, (2001), pp. 193-198.

[6] J. H. Lee, J. H. Kim, S. W. Hwang, W. J. Lee, H. K. Yoon, H. S. Lee and S. S. Hong, "High level expression of antimicrobial peptide mediated by a fusion partner reinforcing formation of inclusion bodies”, Biochem. Biophys. Res. Commun., vol. 277, (2000), pp. 575-580.

[7] K. W. Miller, R. Schamber, Y. L. Chen and B. Ray, "Production of active chimeric pediocin AcH in Escherichia coli in the absence of processing and secretion genes from the Pediococcus pap operon", Appl. Environ. Microbiol., vol. 64, (1998), pp. 14-20.

[8] S. H. Pyo, J. H. Lee, H. B. Park, J. S. Cho, H. R. Kim, B. H. Han and Y. S. Park, "Expression and purification of a recombinant buforin derivative from Escherichia coli”, Process Biochem, vol. 39, (2004), pp. 1731-1736.

[9] X. C. Rao, S. Li, J. C. Hu, X. L. Jin, X. M. Hu, J. J. Huang, Z. J. Chen, J. M. Zhu and F. Q. Hu, “A novel carrier molecule for high-level expression of peptide antibiotics in Escherichia coli”, Protein Expr. Purif., vol. 36, (2004), pp. 11-18.

[10] L. Zhang, T. Falla, M. Wu, S. Fidai, J. Burian, W. Kay and R. E. W. Hancock, "Determinants of recombinant production of antimicrobial cationic peptides and creation of peptide variants in bacteria", Biochem. Biophys. Res. Commun., vol. 247, (1998), pp. 674-680.

[11] S. Y. Lee, "High cell-density culture of Escherichia coli”, Trends Biotechnol., vol. 14, (1996), pp. 98105.

[12] D. K. Sahoo and G. P. Agarwal, "Effect of oxygen transfer on glycerol biosynthesis by an osmophilic yeast Candida magnoliae I2B”, Biotechnol Bioeng., vol. 78, (2002), pp. 545-555.

[13] V. Saraswat, D. Y. Kim, J. Lee and Y.-H. Park, "Effect of specific production rate of recombinant protein on multimerization of plasmid vector and gene expression level”, FEMS Microbiol. Lett., vol. 179, (1999), pp. 367-373.

[14] C. S. Shin, M. S. Hong, C. S. Bae and J. Lee, "Enhanced production of human miniproinsulin in fedbatch cultures at high cell density of Escherichia coli BL21(DE3) [pET-3aT2M2]”, Biotechnol.Prog., vol. 13, (1997), pp. 249-257.

[15] X. Wang, X. Lin, J. A. Loy, J. Tang and X. C. Zhang, "Crystal structure of the catalytic domain of human plasmin complexed with streptokinase”, Science, vol. 281, (1998), pp. 1662-1665.

[16] N. N. Dedhia, R. Richins, A. Mesina and W. Chen, "Improvements in recombinant protein production in ppGpp-deficient Escherichia coli”, Biotech.Bioeng., vol. 53, (1997), pp. 379-386.

[17] G. L. Miller, "Use of dinitrosalicylic acid (DNS) for determination of reducing sugars", Anal, Chem., vol. 31, no. 3, (1959), pp. 426-428.

[18] D. Goyal, D. K. Sahoo and G. Sahni, "Hydrophobic interaction expanded bed adsorption chromatography (HI-EBAC) based facile purification of recombinant streptokinase from E. coli inclusion bodies”, Chromatogr, vol. B. 850, (2007), pp. 384-391.

[19] J. Sambrook, E. F. Fritsch and T. Maniatis, "Molecular Cloning: A Laboratory Manual”, Cold Spring Harbor Laboratory Press, Cold Spring Harbor, New York, USA, (1989), pp. 18.43-18.55.

[20] A. Asoodeh, H. Naderi Manesh, M. Mirshahi and B. Ranjbar, "Purification and characterization of antimicrobial and antifungal and non haemolytic peptide from Rana Ridibunda”, Journal of sciences, Islamic republic of Iran, vol. 15, (2004), pp. 303-9.

[21] Z. Xu, Z. Zhong, L. Huang, L. Peng, F. Wang and P. Cen, "High level production of bioactive human beta-defensin-4 in Escherichia coli by soluble fusion expression”, Appl. Microbiol. Biotechnol., vol. 72, (2006), pp. 471-479.

[22] G. Zhong, A. Yu, B. Shi, Y. Liu and C. Wu, "Pilot-scale production and purification of a staphylokinase based fusion protein over-expressed in Escherichia coli”, Front. Biol. China, vol. 4, no. 1, (2009), pp. 75-81.

[23] J.-H. Kim, S.-L. Wong and B.-G. Kim, "Optimization of Staphylokinase Production in Bacillus subtilis Using Inducible and Constitutive Promoters”, Biotechnol. Bioprocess Eng., vol. 6, (2001), pp. 167-172. 
[24] S. C. Lee, B. H. Young, T. H. Lee, Y. K. Chang and H. N. Chang, "Characteristics and performance of an auto tuning proportional integral derivative controller for dissolved oxygen concentration", Biotechnol.Prog., vol. 10, (1994), pp. 447-450.

[25] A. De León, A. P. Barba de la Rosa, H. Mayani, E. Galindo and O. T. Ramírez, "Two useful dimensionless parameters that combine physiological, operational and bioreactor design parameters for improved control of dissolved oxygen”, Biotechnology Letters,vol. 23, (2001), pp. 1051-1056.

[26] M. A. Trujillo-Roldon, C. Pena, O. T. Ramirez and E. Galindo, "Effect of oscillating dissolved oxygen tension on the production of alginate by Azotobacter vinelandii", Biotechnol.Prog., vol. 17, (2001), pp. 1042-1048.

[27] D. W. Zabriskie and E. J. Arcuri, "Factors influencing productivity of fermentations employing recombinant microorganisms”, Enz. Microb. Technol., vol. 8, (1986), pp. 706-717.

[28] A. M. Sanden, I. Prytz, I. Tubulekas, C. Forberg, H. Le, A. Hektor, P. Neubauer, Z. Pragai, C. Harwood, A. Ward, A. Picon, J. Teixeira de Mattos, P. Postma, A. Farewell, T. Nyström, S. Reeh, S. Pedersen and G. Larsson, "Limiting factors in Escherichia coli fed batch production of recombinant proteins", Biotechnol.Bioeng., vol. 81, (2003), pp. 158-166.

[29] D. H. Kweon, N. S. Han, K. M. Park and J. H. Seo, "Over production of Phytolaccainsularis protein in batch and fed-batch culture of recombinant Escherichia coli”, Process Biochem., vol. 36, (2001), pp. 537-542.

[30] D. W. Zabriskie, D. A. Wareheim and M. J. Polansky, "Effect of fermentation feeding strategies prior to induction of expression of a recombinant malaria antigen Escherichia coli”, Ind. Microbiol., vol. 2, (1987), pp. 87-95.

[31] X. Li, J. W. Robbins Jr and K. B. Taylor, "The production of recombinant betagalactosidase in Escherichia coli in yeast extract enriched medium”, Ind. Microbiol., vol. 5, (1990), pp. 85-94.

[32] H.-L. Jiang, Q. He, Z. He, C. L. Hemme, L. Wu and J. Zhou, "Continuous Cellulosic Bioethanol Fermentation by Cyclic Fed-Batch Co-Cultivation”, Applied and Environmental Microbiology, Published online ahead of print, (2012) December 28.

[33] R. Fike, "Nutrient Supplementation Strategies for Biopharmaceutical Production”, Part 2: Feeding for Optimal Recombinant Protein Production. BioProcess Int., vol. 7, no. 11, (2009), pp. 46-52.

[34] P. J. Carter, "Introduction to current and future protein therapeutics: A protein engineering perspective", Experimental cell research, vol. 317, (2011), pp. 1261-1269.

[35] Y. Wang, Y. Jiang, T. Gong, X. Cui, W. Li, Y. Feng, B. Wang, Z. Jiang and M. Li, "High-Level Expression and Novel Antifungal Activity of Mouse Beta Defensin-1 Mature Peptide in Escherichia coli”, Appl Biochem Biotechnol., vol. 160, (2010), pp. 213-221.

[36] H.-K. Kim, D.-S. Chun, J.-S. Kim, C.-H. Yun, J.-H. Lee, S.-K. Hong and D.-K. Kang, "Expression of the cationic antimicrobial peptide lactoferricin fused with the anionic peptide in Escherichia coli”, Appl Microbiol Biotechnol., vol. 72, (2006), pp. 330-338.

[37] L. Zhou, Q. Lin, B. Li, N. Li and S. Zhang, "Expression and purification the antimicrobial peptide CM4 in Escherichia coli”, Biotechnol Lett., vol. 31, (2009), pp. 437-441.

[38] X.-L. Jing, X.-G. Luo, W.-J. Tian, L.-H. Lv, Y. Jiang, N. Wang and T.-C. Zhang, "High-Level Expression of the Antimicrobial Peptide Plectasin in Escherichia coli”, Curr Microbiol., vol. 61, (2010), pp. 197-202.

[39] G. Q. Wu, L. X. Li, J. X. Ding, L. Z. Wen and Z. L. Shen, "High-Level Expression and Novel Purification Strategy of Recombinant Thanatin Analog in Escherichia coli”, Curr Microbiol., vol. 57, (2008), pp. 95-101.

[40] F. Fan, Y. Wu and J. Liu, "Expression and purification of two different antimicrobial peptides, PR-39 and Protegrin-1 in Escherichia coli”, Protein Expression and Purification, vol. 73, (2010), pp. 147-151.

[41] Z. Xu, Z. Zhong, L. Huang, L. Peng, F. Wang and P. Cen, "High-level production of bioactive human beta-defensin-4 in Escherichia coli by soluble fusion expression”, Appl Microbiol Biotechnol., vol. 72, (2006), pp. 471-479.

[42] L. Huang, C. Bun Ching, R. Jiang and S. Su Jan Leong, "Production of bioactive human beta-defensin 5 and 6 in Escherichia coli by soluble fusion expression”, Protein Expression and Purification, vol. 61, (2008), pp. 168-174. 
International Journal of Bio-Science and Bio-Technology

Vol.5, No.5 (2013) 